\title{
Vertebrate trackways in the Parrsboro Formation (upper Carboniferous) at Rams Head, Cumberland County, Nova Scotia
}

\author{
David J. Mossman ${ }^{1}$ and Robert G. Grantham ${ }^{2}$ \\ 'Department of Geography, Mount Allison University, 14 Main Street, Sackville, \\ New Brunswick E4L 1E6, Canada \\ ${ }^{2}$ Nova Scotia Museum of Natural History, 1747 Summer Street, Halifax, Nova Scotia \\ B3H 3A6, Canada
}

Date Received: January 8, 2000

Date Accepted: April 25, 2000

\begin{abstract}
Vertebrate trace fossils are reported from the upper Parrsboro Formation at Rams Head, west of Parrsboro, Nova Scotia. They occur as casts of tetrapod trackways. The trackmakers thrived in a floodplain setting vegetated with tree ferns. Pseudobradypus erneri Schmidt, represented by three trackways, has previously been reported from Germany. It is interpreted as having been produced by a cotylosaur and occurs in association with several scattered footprints and poorly preserved trackways of Hylopus hardingi Dawson; microsaurian-produced ichnotaxa are represented by Dromilopus quadrifidus Matthew and Cursipes dawsoni Matthew. Assignment of these trace fossils to the late Namurian to Westphalian A (upper Carboniferous) accords with the palynologically deduced age of the strata. As such, the sequence, which hosts the trace fossils, is stratigraphically equivalent to the Coal Mine Point Member of the Joggins Formation.
\end{abstract}

Des traces de vertébrés fossilisés sont signalées dans l'étage supérieur de la formation de Parrsboro, à Rams Head, à l'ouest de Parrsboro, en Nouvelle-Écosse. Elles se manifestent sous forme de sillons de contre-empreintes de tétrapodes. Les créatures qui ont laissé ces traces vivaient dans une plaine inondable dont la végétation se composait de fougères géantes. L'espèce Pseudobradypus erneri de Schmidt, qui a laissé trois sillons d'empreintes, a déjà été signalée en Allemagne. On croit qu'il pourrait s'agir d'un cotylosaurien et les empreintes s'accompagnent de plusieurs autres empreintes dispersées et mal préservées de l'espèce Hylopus hardingi de Dawson; des traces fossilisées auraient été laissées par des microsauriens comme le Dromilopus quadrifidus de Matthew et le Cursipes dawsoni de Matthew. L'attribution de ces empreintes fossilisées au namurien supérieur et au westphalien A (Carbonifêre supérieur) corroborerait l'âge palynologique estimé de cet étage. De fait, la séquence qui renferme les traces fossilisées s'apparente au plan stratigraphique aux vestiges trouvés dans le secteur Coal Mine Point de la formation de Joggins.

Traduit par la rédaction

\section{INTRODUCTION}

In June, 1997, several trackways of quadrupedal vertebrates were discovered by Cody McLellan in cliff exposures of the fluvial-lacustrine Parrsboro Formation at Rams Head about $4 \mathrm{~km}$ from the mouth of Diligent River along the coast west of Parrsboro, Nova Scotia (Fig. 1). The Parrsboro Formation is stratigraphically equivalent to the Joggins Formation, famous for its classic Carboniferous section and for having provided the first evidence for terrestrial tetrapods in early Carboniferous rocks (Carroll et al. 1972; Gibling 1987; Calder 1998). Following site investigations at Rams Head in 1997, a portion of the trace fossil-bearing stratum was excavated by personnel of the Nova Scotia Museum of Natural History (NSMNH) and the Fundy Geological Museum (FGM) in order to preserve the trace fossils from rapid erosion by tide and wave action. The best preserved trackways, together with several isolated individual footprints, are now housed at the FGM, Parrsboro. Four ichnospecies are recognized, including scattered and faintly preserved footprints of two microsaurian-produced ichnospecies. Together with associated fossil flora and sedimentary structures, these provide a glimpse of life under subaerial conditions during Pennsylvanian time.

The trace fossils are preserved in convex hyporelief on the base of a reddish-brown fine- to medium-grained sandstone (Fig. 2). At Rams Head, the largest ichnospecies is represented by four trackways originally impressed in substrate of different consistency and water content. The next largest ichnospecies is represented by scattered individual footprints and as several sets of faintly impressed trackways, the best preserved of which obliquely crosses one of the better preserved larger trackways. The main purpose of this communication is to briefly record and more fully document the morphologies of the two larger ichnospecies.

\section{STRATIGRAPHY, STRUCTURE, AND SEDIMENTOLOGY}

The strata at Rams Head belong to the upper part of the Parrsboro Formation, the lowest stratigraphic unit of the Cumberland Group (Naylor and Kennedy 1997; Calder 1998); overturned at the fossil locality, they strike roughly perpendicular to the coastline and dip steeply eastward. Earlier inclusion of the Parrsboro Formation in the underlying Mabou

"It has often happened to geologists, as to other explorers of new regions, that footprints on the sand have guided them to the inhabitants of unknown lands"

J.W. Dawson - Acadian Geology (1878, p. 353) 


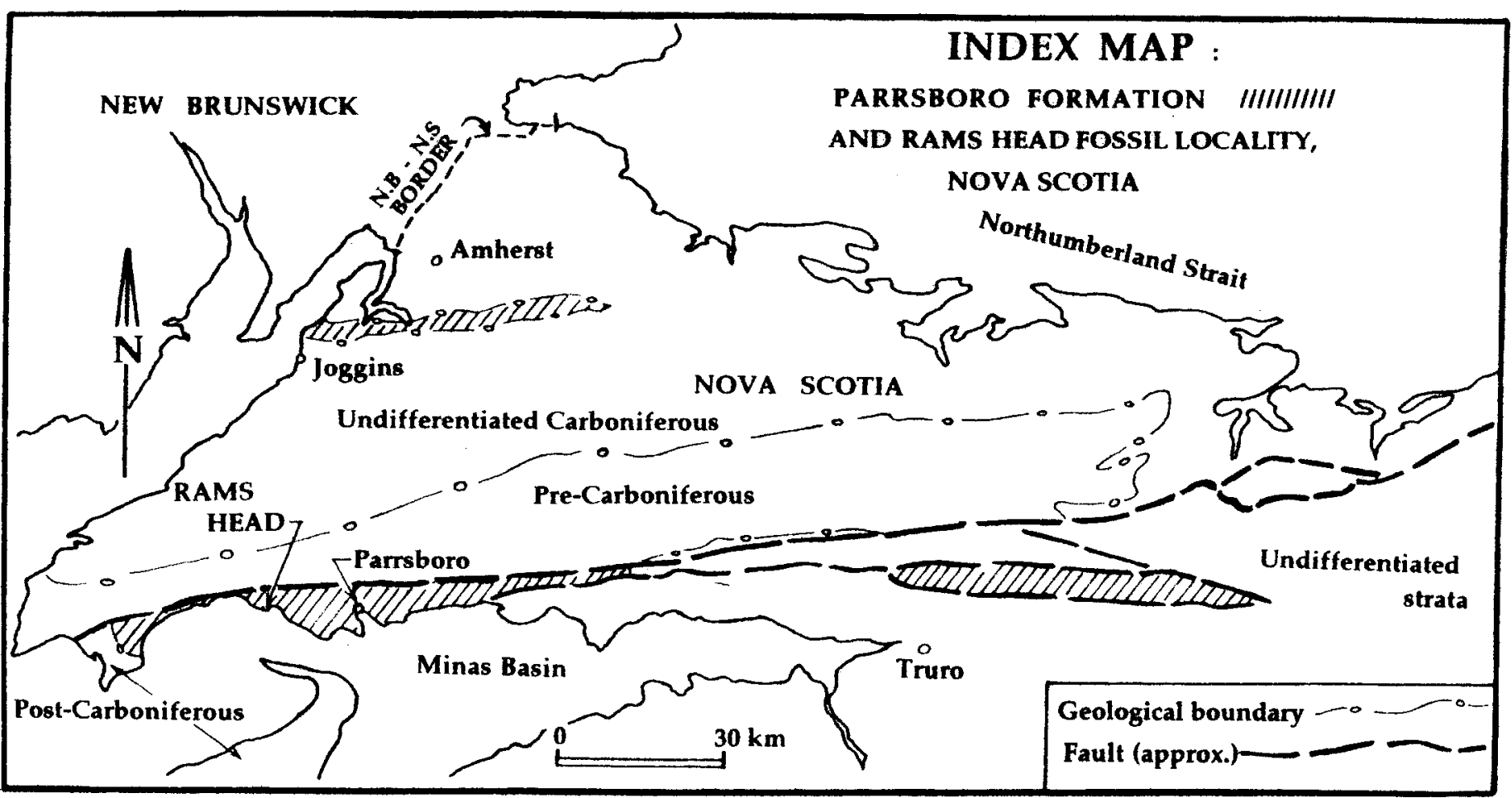

Fig. 1. Location map of the vertebrate trace fossil locality at Rams Head, near Parrsboro, Nova Scotia (after Naylor and Kennedy 1997).

Group (Belt 1965) has not endured. However, the red and grey facies subdivisions proposed by Belt (1965) serve very well to distinguish a lower red facies (ca. $800 \mathrm{~m}$ thick) from an overlying "grey facies" (ca. $1700 \mathrm{~m}$ thick) in the Parrsboro Formation. Naylor and Kennedy (1997, p. 124) equated the Parrsboro Formation with the lower portion of the Cumberland Group as defined by Ryan et al. (1991) (Fig. 3).

The upper part of the (predominantly lacustrine) Parrsboro Formation comprises grey and red mudrock, dark coloured shale and intervals of red and grey sandstone; lack of thick channel sandstone distinguishes it from the (predominantly fluvial) lower Parrsboro Formation, but otherwise poorly drained and well-drained floodplain assemblages are alike in both formations (Naylor and Kennedy 1997). The vertebrate tracks that are the subject of this paper occur in a well-drained floodplain assemblage of red and grey mudrock (dominantly siltstone) that contains rooted horizons, raindrop impressions, desiccation cracks and a variety of other sedimentary structures including dewatering structures (see Naylor and Kennedy 1997; McCarthy 1999).

Results of palynological studies by M.S. Barss (in D'Orsay 1986, p. 119) indicate a late Namurian to an early Westphalian age for the Parrsboro Formation, a conclusion since confirmed by Dolby (in Naylor and Kennedy 1997). Frond impressions of Alethopteris sp. (Fig. 4) and Calamites sp. stems (Fig. 2) are common at the Rams Head trackway horizon and at various other horizons stratigraphically above and below the trackway locality. The exact location of this studied locality is at the $73.1 \mathrm{~m}$ mark at the top of unit \#9 in a $152.5 \mathrm{~m}$ stratigraphic sequence mapped by McCarthy (1999).

\section{SYSTEMATIC DESCRIPTION}

\author{
Class: Reptilia \\ Subclass: Cotylosauria Cope, 1880 \\ Order: Captorhinomorpha Watson, 1917 \\ Ichnogenus: Pseudobradypus (Herpetichnus) erneri \\ Schmidt, 1963 \\ (Fig. 5, Table 1)
}

Description: Trackway of a quadruped (Fig. 5) exhibiting pronounced body drag. Footprints plantigrade, manus and pes pentadactyl. Manus smaller than pes and slightly behind; mostly obscured due to near total secondary overlap by pes. Pace exceeds track breadth. Digits I to IV of pes directed forward, digit V obliquely outward; digits II and III are the longest. Internal width (width between tracks) consistent at about $10 \mathrm{~cm}$. External trackway width is $21.0 \mathrm{~cm}$.

The host rock is dark grey, fine- to medium-grained sandstone, the upper surface of which retains traces of an overlying (see also Fig. 6) thin reddish-brown mudstone. Small-scale cross-bedding present in the sandstone about $2 \mathrm{~cm}$ below the trackway horizon suggests material transport was downdip, as seen in Fig. 6.

Material: Four trackways, only two of which (\#1 - specimen a and \#4 - specimen b) are sufficiently well preserved to allow detailed diagnosis. Specimen a consists of ten successive impressions over a distance of $90 \mathrm{~cm}$, each of which, unfortunately, is the result of near total overlap of manus by pes. Specimen b, the smaller of the two, consists of 9 successive pairs of footprints of varying degrees of preservation but provides a partial set of well-preserved footprints (RM - right manus, RP - right pes) that contribute important details. It is located $30 \mathrm{~cm}$ above trackway \#1 (out 


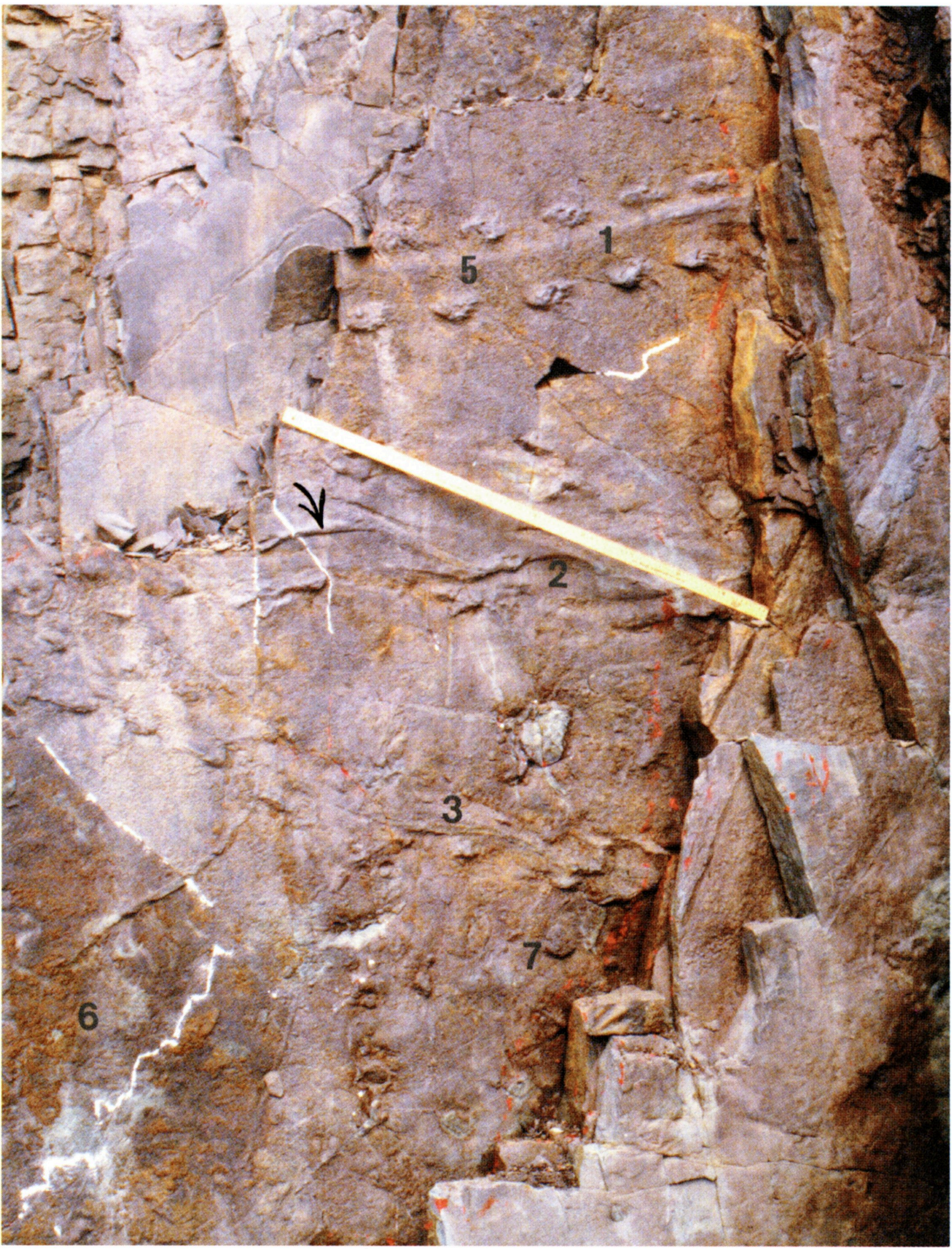




\section{PARRSBORO \\ AREA}

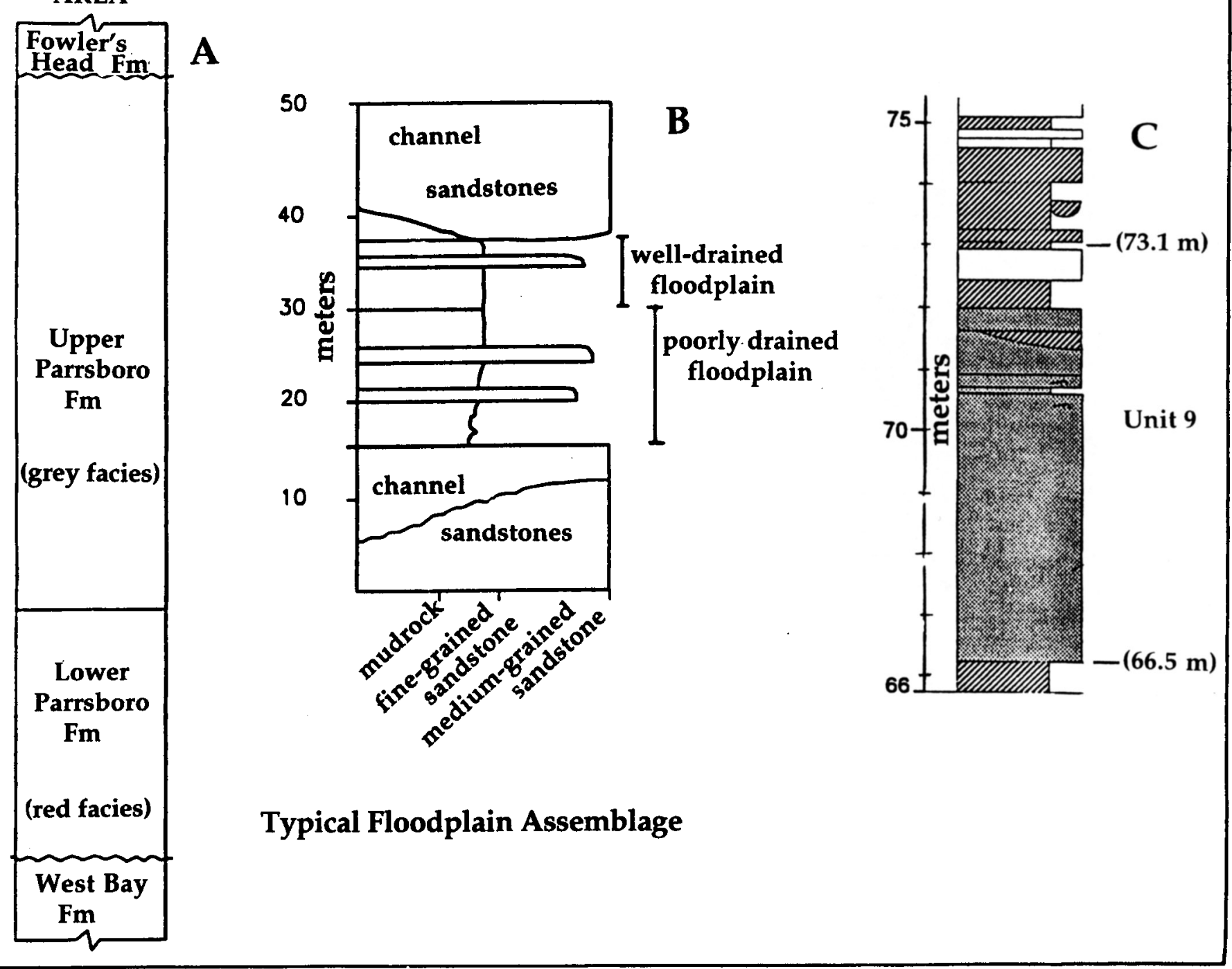

Fig. 3. Stratigraphic scheme applicable to: A) thickness of the Parrsboro Formation and contact relationships with overlying and underlying formations in the Parrsboro area, and B) well-drained floodplain assemblages typical of the upper (and lower) Parrsboro Formation (after Naylor and Kennedy 1997, pp. 117-119), and C) unit \#9 (66.5 m-73.1 m), within a $152.5 \mathrm{~m}$ stratigraphic interval at the trace fossil locality in the upper Parrsboro Formation at Rams Head (after McCarthy 1999); cross-hatching refers to relatively finer-grained layers (e.g., siltstone). Trace fossilbearing stratum (clear) is at the top $(73.1 \mathrm{~m})$ of unit \#9.

Fig. 2. Photograph looking west and showing trace fossil-bearing rock surface prior to collection in early fall, 1997, by the FGM. Highlights include: 1 . The best preserved large vertebrate trackway (trackway \# 1, left to right, above metre stick) and three other trackways (2, 3, and 4). Trackways \#2 and \#3 (right to left, below metre stick) are subparallel to trackway \#1; a fourth trackway (trackway \#4, right to left) is out of view at top right, $30 \mathrm{~cm}$ above trackway \#1. 5. Numerous small footprints and remnant portions of trackways (not visible at this scale and with this illumination - but for example, see Fig. 8); 6. Location of fossil (Alethopteris sp.) fronds; 7. Calamites stalk. White lines are glue used to repair fractures. Photograph by K. Adams. 


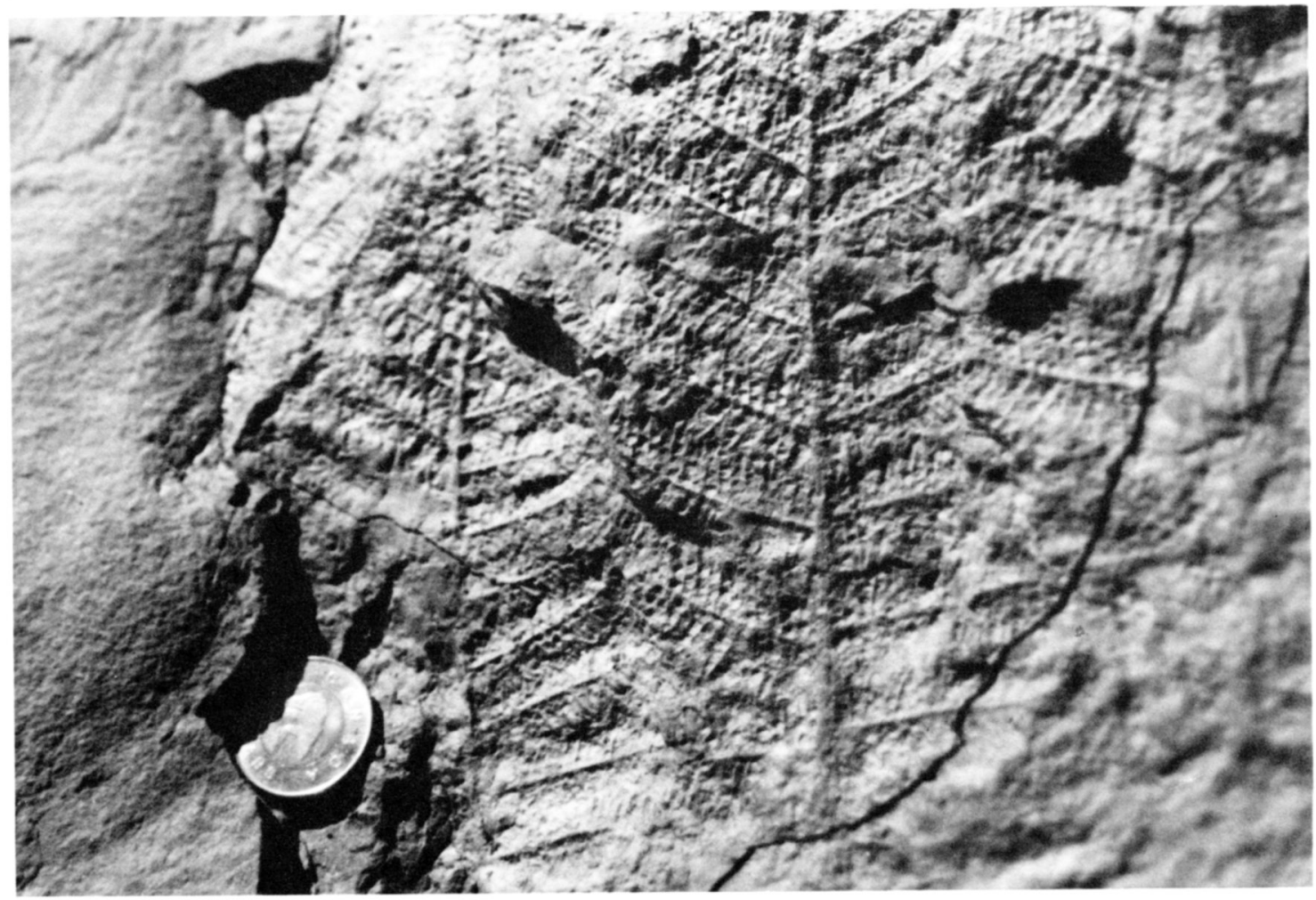

Fig. 4. Photograph shows impression of Alethopteris sp. present on trackway-bearing horizon at Rams Head. Coin is $2.7 \mathrm{~cm}$ in diameter. Photograph by Tim Fedak.

Table 1. Comparison of measurements of footprints of the holotype Pseudobradypus (Herpetichnus) erneri Schmidt, 1963 from the Ruhrgebiet, Germany, and figured specimens from Rams Head.

\begin{tabular}{|c|c|c|c|}
\hline & Holotype & Hypotype a & Hypotype b \\
\hline Pes length $(\mathrm{cm})$ & $28-30$ & ca. 10.5 & 7 \\
\hline Pes width $(\mathrm{cm})$ & $19-21$ & ca. 7 & 6.5 \\
\hline Manus length (cm) & $24-26$ & ca. 8.5 & 5 \\
\hline Manus width (cm) & $18-20$ & ca. 5.5 & n.d. \\
\hline Stride $(\mathrm{cm})$ & ca. 100 & ca. 18 & n.d. \\
\hline Pace $(\mathrm{cm})$ & - & ca. 18 & n.d. \\
\hline Width of trackway $(\mathrm{cm})$ & ca. 45 & ca. 20 (external) & n.d. \\
\hline Step angle (degrees) & n.d. & 60 & n.d. \\
\hline \multicolumn{4}{|l|}{ Digit length in $\mathrm{cm}$ (manus, pes) } \\
\hline I & $4.0,2.5$ & 1.0 (pes) & ? \\
\hline II & $4.3,3.2$ & 3.0, n.d. & 2.5, n.d. \\
\hline III & $4.5,4.0$ & 3.0, n.d. & $3.0,2.5$ \\
\hline IV & $4.0,3.0$ & 3.0, n.d. & $3.5,2.4$ \\
\hline $\mathbf{v}$ & $3.5,1.5$ & 2.5, n.d. & $3.3,2.5$ \\
\hline \multicolumn{4}{|c|}{ Interdigital angles in degrees (pes) } \\
\hline I-IV & 56 & 50 & 55 \\
\hline I-V & 84 & 80 & 80 \\
\hline \multicolumn{4}{|c|}{ Interdigital angles in degrees (manus) } \\
\hline I-IV & 68 & n.d. & $55(?)$ \\
\hline $\mathbf{I}-\mathbf{V}$ & ca. 88 & n.d. & n.d. \\
\hline
\end{tabular}

n.d. $=$ not determined 


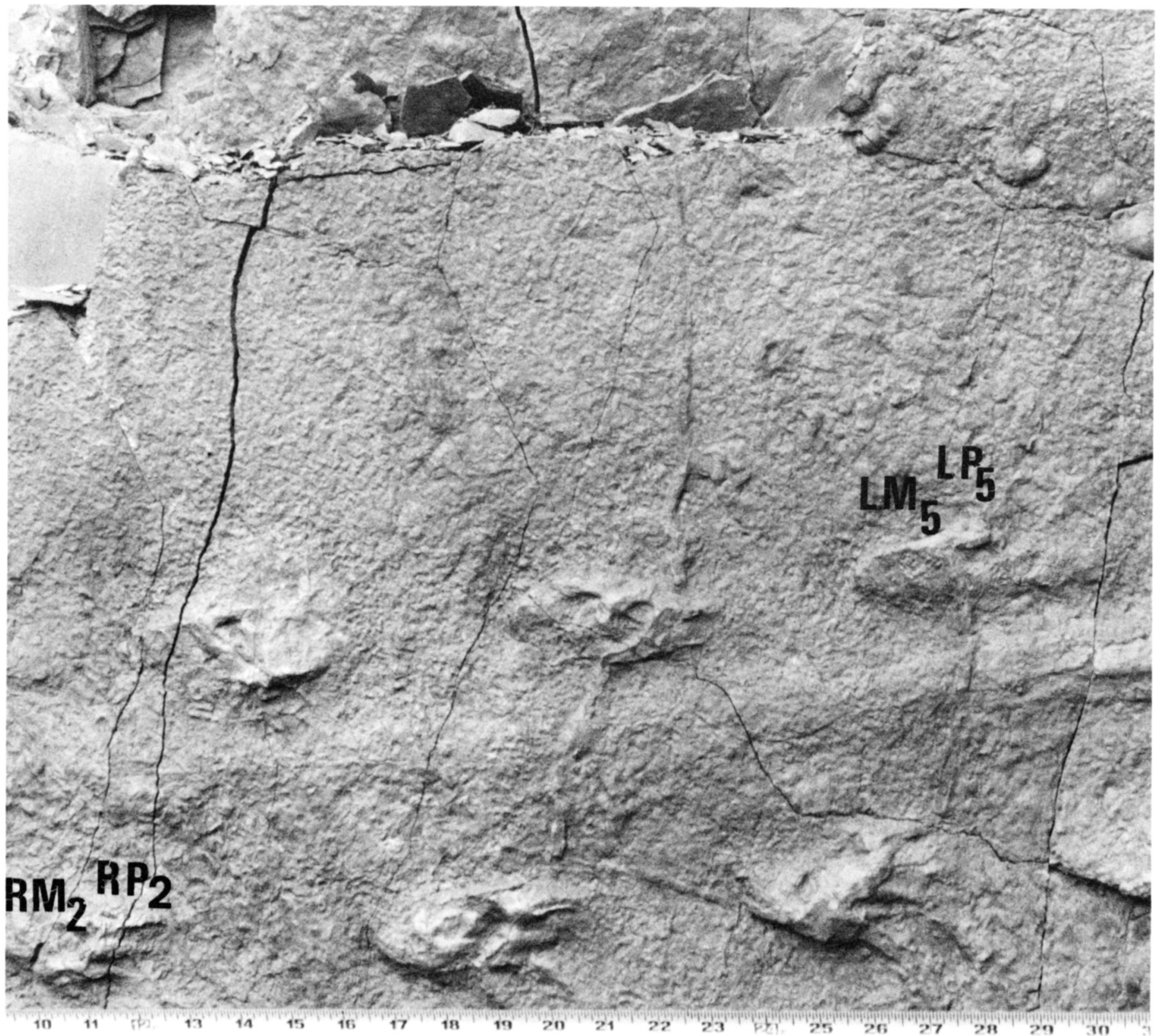

\section{Interpretive sketch based on several footprints}

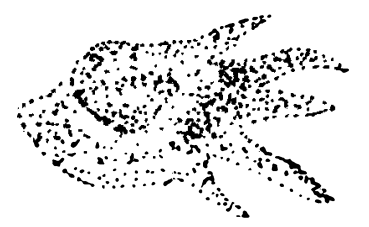

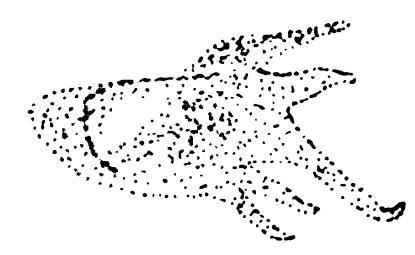

$2 \mathrm{~cm}$
Fig. 5. Photograph shows trackway \#1 of Pseudobradypus (Herpetichnus) erneri Schmidt, 1963; natural overhead lighting is from the upper left (southwest). Six successive pairs of footprints $\left(\mathrm{RM}_{2}, \mathrm{RP}_{2}\right.$ through $\left.\mathrm{LM}_{5}, \mathrm{LP}_{6}\right)$ of a total of ten in trackway \#1 of Pseudobradypus erneri shown in Figure 2. Inset shows interpretive sketch of $\mathrm{RP}_{3}, \mathrm{RM}_{4}$ ). Based on several photographs taken at different angles of illumination. Scale bar $=2 \mathrm{~cm}$. Photograph by $R$. Grantham. 


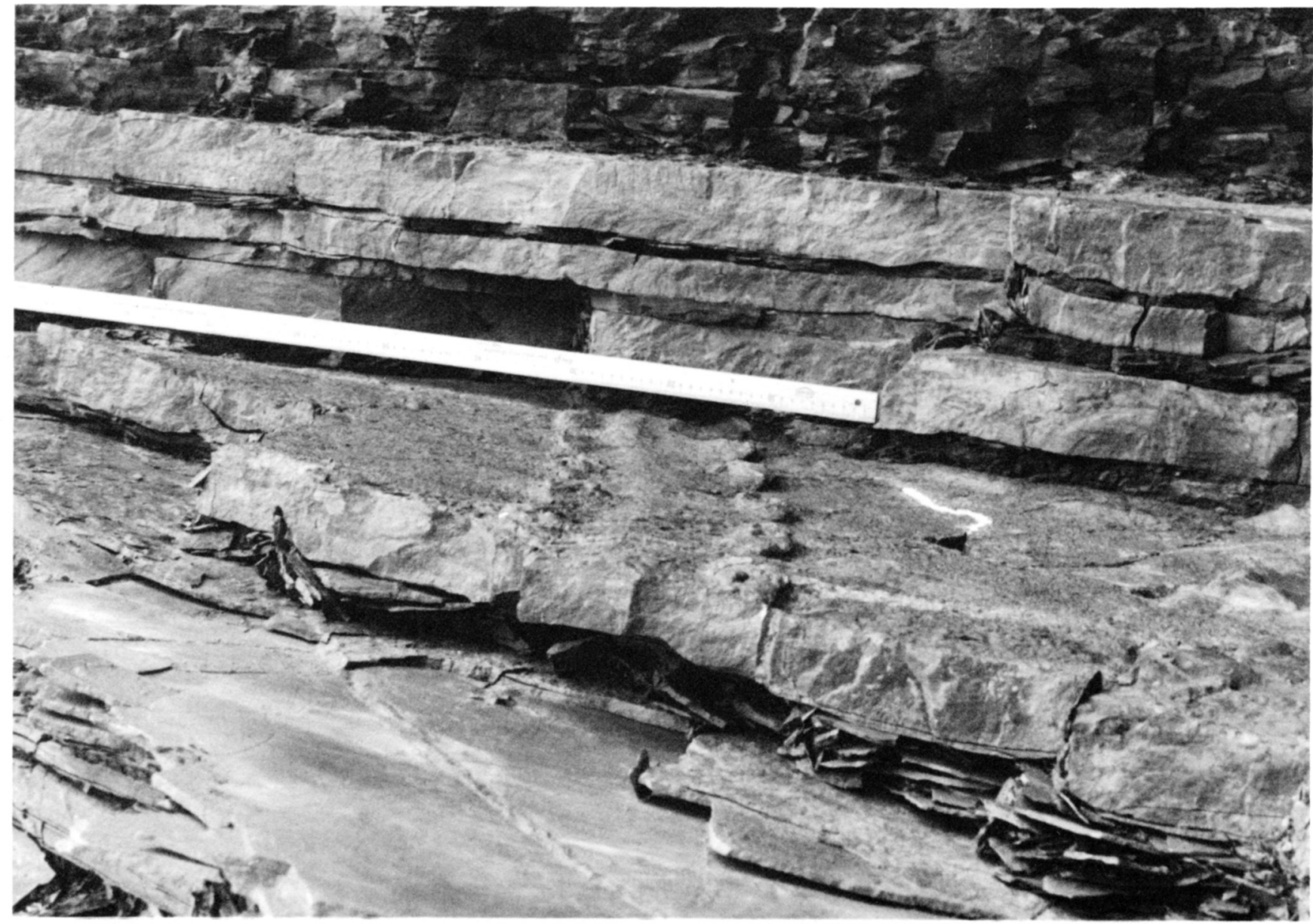

Fig. 6. Photograph of edge-on view of the trace fossil-bearing horizon shows unusual perspective of trackway \#1 (Pseudobradypus erneri) and its asymmetrical body-drag (centre of photograph). Overlying (and underlying) this ca. $10 \mathrm{~cm}$-thick sandstone horizon is an approximately 2 $\mathrm{cm}$-thick mudstone (directly under the metre stick) upon the lower portion of which the trackmaker would have traversed and where finer details of the trackway might well have been initially better preserved; curved white line (just below the trackway) is glue-filled fracture (see text for discussion). Photograph by D. Mossman.

of view at top right in Fig. 2) and extends for a distance of 25 $\mathrm{cm}$. Trackways are conserved in FGM on the surface of numerous fitted sandstone slabs and also on a latex mould (peel) (specimen \# FGM-999-GF.12) approximately $3 \mathrm{~m} \mathrm{x} 1$ $\mathrm{m}$. Total length of trackway \#1 is about $90 \mathrm{~cm}$.

Dimensions: The footprints of trackway \#1 are not equally well-impressed. Those on the left hand side of the trackway are much less clearly impressed than those on the right. The trackway comes very close to what Peabody (1959) termed "primary couplings", i.e., the hind-footprints have almost totally obliterated the fore-footprints. According to Haubold (1971, p. 27), this feature, together with the slow gait evident in trackway \#1 (Figs. 5 and 6), is characteristic of Pseudobradypus. Further features include plantigrade pentadactyl footprint impressions of manus and pes. Detailed comparisons between holotype and figured specimens are shown in Table 1. Although poor preservation and overlapping conditions of manus and pes do not facilitate comparisons, there is nevertheless good general resemblance between holotype and figured specimens although the former is more than twice as large as the latter.

Measurements given in Table 1 for the Rams Head specimen are based on the best impressions in trackway \#1, specifically the average for $R P_{2}, R_{3}$ and $R P_{3}$. These should be compared with measurements of footprints $\left(\mathrm{LM}_{1}, \mathrm{LP}_{2}\right)$ of specimen b in trackway \#4 (see Fig. 7). Trackway \#4 was created by a slightly smaller individual than that which made trackway \#1 (see Table 2). Apart from differences in creature size, the contrast in stride, pace, step angle and absence of primary coupling in trackway \#1 are directly attributable to the relatively drier and possibly firmer ground in which trackway \#4 was created. It should be noted that in view of the different sizes of the individual trackmakers, and the different ground conditions, these types of measurements are highly subjective.

Remarks: The holotype, from the Westphalian A, Saarland, is housed in the Geologisches Museum der Saarbergwerke, Germany. Trackway \#1 exhibits a curiously asymmetrical body drag with respect to the footprints. Possible explanations include: injury; passage of the animal along an inclined surface (shoreline or stream bank); modification by erosion of an originally symmetrical body drag; efforts of the animal to turn from a straight path. The latter is the favoured explanation. An excellent illustration of the phenomenon is seen to advantage in a longer trackway figured by Mossman 
a)

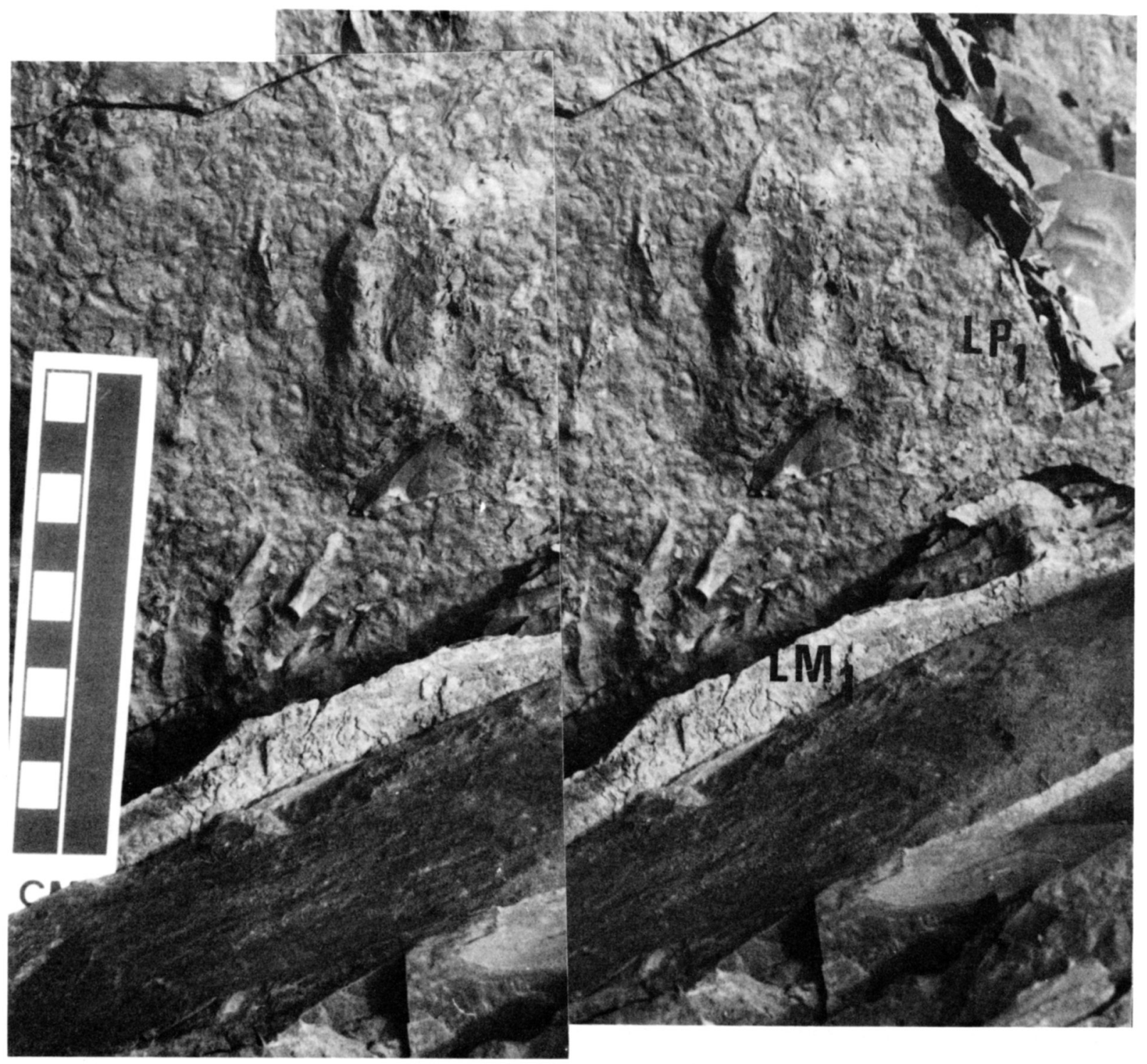

b)

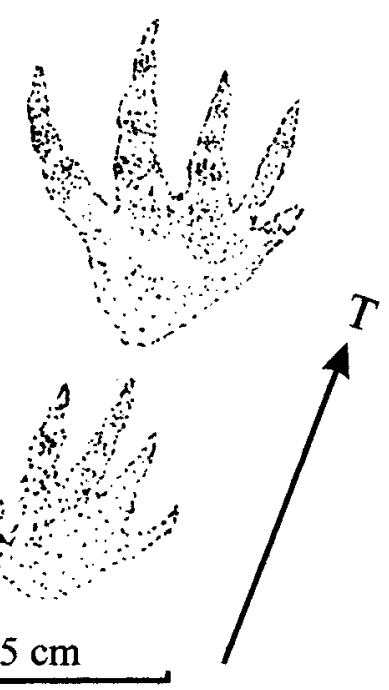

Fig. 7. a) Stereographic photographs of pair of footprints $\left(\mathrm{LM}_{1}, \mathrm{LP}_{1}\right)$ of Pseudobradypus erneri from trackway \#4 (LM was only partially recovered). b) Interpretive sketch of Pseudobradypus erneri in trackway \#4 from two of the better preserved pes $\left(L P_{1}\right.$ and $\left.L P_{2}\right)$ and a combination of several partially preserved mani impressions including $\mathrm{LM}_{1}$; $\mathrm{T}$ shows the trackway direction, which intersects trackway \#1 at about $20^{\circ}$. Scale bar $=5 \mathrm{~cm}$. Photograph by D. Mossman. 
a)

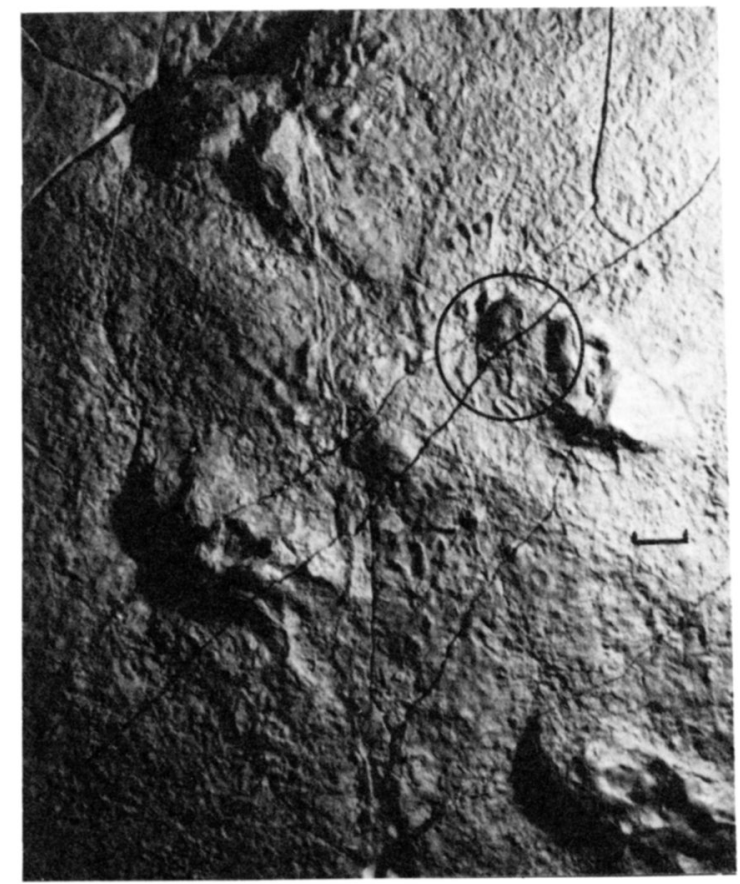

b)

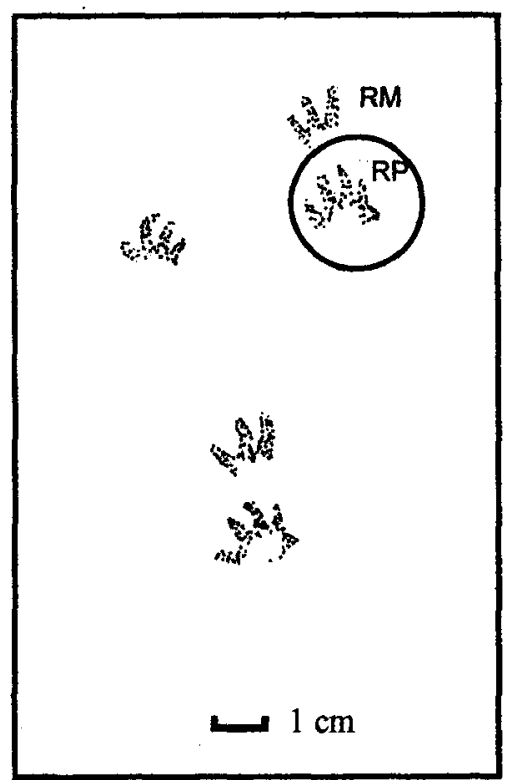

Fig. 8. a) A portion of trackway \#5, Hylopus hardingi. Circle shows partially preserved impressions of three of one pair of a total of 11 poorly preserved successive pairs of footprints. Note that the RP (in circle) overprints earlier footprint(s) of Pseudobradypus erneri. Scale bar $=1 \mathrm{~cm}$. b) Interpretive sketch of Hylopus hardingi footprints. Scale bar $=1 \mathrm{~cm}$. Photograph by D. Mossman.

and Place (1989, fig. 3, p. 593) from Permian strata on Prince Edward Island.

Trackways 2 and 3 are believed to have been made by trackmakers similar to those that made trackways \#1 and \#4. Unfortunately, however, they provide inadequate details to confirm ichnospecific assignment. The producer of trackway \#2 seems to have been the largest of all four. Trackways \#2 and \#3 each extend just over one meter (right to left) in a direction opposite to that of the creature that made trackway $\# 1$. The producer of trackway \#2 needed to propel itself (cf. Peabody 1959, plate 5E, p. 59) by pushing with its tail (arrow in Fig. 2 shows pressure ridges, i.e., build-up of material), indicating water-saturated ground conditions, or possibly very shallow water conditions at the time of passage. The somewhat smaller (judging by footprint size and trackway width) creature that made trackway \#3 may have had an easier passage between the seed fern stalks dotting the local landscape. With a short stride and low step angle, it left behind no less than 15 successive footprint impressions. Overall, despite its apparently inefficient walking mode, the trackway appears more reptilian than amphibian, an interpretation confirmed by the evidence of claws, and on specimen $b$ the presence of phalangeal pads (see Fig. 7). The relatively clear impressions of this specimen bodes well for the possible future discoveries of a well-preserved ichnofauna in this area. Although recorded widely throughout Europe (Haubold 1974; 1984) Pseudobradypus erneri is limited to the Westphalian A stage of the Carboniferous (Schmidt 1963). This is its first reported occurrence in Nova Scotia.

\author{
Class: Amphibia \\ Subclass: Lepospondylia Zittel, 1887 \\ Order: Temnospodylia Zittel, 1887 \\ Superfamilia: Edopsoidea Romer, 1945 or Eryopoidea \\ Romer, 1945 \\ Ichnospecies: Hylopus hardingi Dawson, 1882
}

(Fig. 8, Table 2)

Description: Quadrupedal trackway showing 11 poorly preserved sets of footprints, manus tetradactyl, slightly smaller than pes; both plantigrade. Pes pentadactyl. Digits of manus and pes well-impressed in several cases, palms and soles less commonly so. Fine details are lacking even on the two best preserved (right hand) sets of footprints (Fig. 8). The trackway appears to overprint the earlier formed much larger reptilian footprints (specifically $\mathrm{RP}_{3}$ and $\mathrm{RM}_{3}$ ) of Pseudobradypus erneri.

Dimensions: Unfortunately, preservation of these footprints, like many others on this slab of fine-grained sandstone, is not good. The measurements given in Table 2 are based specifically on the average of two sets of footprints $\left(R M_{5}, R P_{5}\right.$ and $R M_{6}, R P_{6}$ ). Maximum length of the footprints is given from back of palm imprint to the tip of digit IV. The maximum width (span) is given from the tip of digit 1 to the tip of digit V (Table 1). Interdigital span is approximately $110^{\circ}$.

Remarks: These footprints are smaller, but correspond in general to those of the type Hylopus hardingi as originally refigured by Matthew (1904) (in Sarjeant and Mossman 1978, p. 287). Isolated remnants of individual or of discrete pairs of 
Table 2. Comparison of measurements of footprints of the type Hylopus hardingi Dawson from Joggins (after Matthew 1904) and the figured specimens from Rams Head.

\begin{tabular}{|c|c|c|}
\hline & Type & Paratype \\
\hline Stride $(\mathrm{mm})$ & 91 & 150 \\
\hline Width of trackway (centre to & & \\
\hline centre in $\mathrm{mm}$ ) & 62 & 120 \\
\hline Manus length (mm) & 22 & 27 \\
\hline Manus width (mm) & 30 & ca. 33 \\
\hline Pes length (mm) & 28 & 34 \\
\hline Pes width (mm) & 33 & 39 \\
\hline Total interdigital span (degrees) & 85 (RM) & - \\
\hline Step angle (degrees) & 100 (RP) & ca. 100 \\
\hline
\end{tabular}

footprints occur elsewhere on this same bedding plane surface (e.g., sample FGM 999Gf. M6 - K6).

\section{MICROSAURIAN FOOTPRINTS}

Two other ichnospecies are represented in convex hyporelief on the principal bedding plane. One is Dromillopus quadrifidus Matthew, 1905 as recently redescribed (Mossman and Grantham 1996), which is present as several isolated footprints (e.g., sample FGM 999Gf, 12 JG. 2). Another, Cursipes dawsoni Matthew, 1903 is represented by a single well-preserved pes impression and several accompanying indistinctly defined impressions (sample FGM 999Gf, $12 \mathrm{Cl}$ B1).

\section{DisCuSSION AND CONCLUSIONS}

The ichnofauna preserved in upper Carboniferous red beds at Rams Head contains early amphibian and reptilian ichnofossils that substantiate the interpretations (Belt 1965; Ryan et al. 1991; Naylor and Kennedy 1997) regarding the age and the origin of the Parrsboro Formation.

Naylor and Kennedy (1997, p. 120) noted, "The red colour, fossil roots and calcrete nodules suggest a floodplain environment that had a low water table that favoured the development of plants and soils". To this description the occurrence of trace fossils indicating abundant animal life must be added. The ichnofauna preserved in upper Carboniferous red beds at Rams Head contains the remains of creatures that thrived under warm and moist conditions within vegetated regions of a floodplain subjected to fluctuating water levels. These are properly terms an "ichnocoenose", an assemblage from a single level of trace fossils representing the activities of an association of living organisms (Casamiquela et al. 1987, p. 43). There are strong indications that, as erosion proceeds, further exposure of this level holds good potential for adding to this ichnocoenose (Naylor and Kennedy 1997; McCarthy 1999). This is perhaps only to be expected given that the Joggins (Coal Mine Point Member) and Boss Point formations are in part coeval with the Parrsboro Formation. Neither should it prove surprising to discover further ichnotaxa here, such as are known in equivalent Pangean strata (e.g., lower Bochum) in parts of Europe.

\section{ACKNOWLEDGEMENTS}

We thank Ken Adams, Director of the Fundy Geological Museum, for the invitation in August, 1997, to study these trackways. Tim Fedak and Dr. Bob Stevens kindly assisted in the field. This research is supported by a grant in aid of research from the Natural Sciences and Engineering Research Council to the senior author.

This paper was presented on September 18, 1999 at the Fundy Geological Museum during a meeting to commemorate the contributions of Sir John William Dawson to education and the science of geology.

\section{REFERENCES}

BELT, E.S. 1965. Stratigraphy and paleogeography of Mabou Group and related facies, Nova Scotia, Canada. Geological Society of America Bulletin, 76, pp. 777-802.

CALDER, J.H. 1998. The Carboniferous evolution of Nova Scotia. In Lyell: The Past is the Key to the Present, Edited by E.J. Blundell and A.C. Scott. Geological Society of London. Special Publication 143, pp. 261-302.

CARROll, R.L., BELT, E.S., DINELy, D.L., BAIRD, D., \& MCGREGOR, D.C. 1972. Vertebrate paleontology of Eastern Canada; Field Excursion A49, International Geological Congress Guidebook, Montreal, 113 p.

Casamiquela, R.M., Demathieu, G.R., Haubold, H., Leonardi, G., \& SARJEANT, W.A.S. 1987. Glossary and Manual of Tetrapod Palaeoichnology. Edited by G. Leonardi. Departemento Nacional da Producao Mineral, Brisilia, Brazil, $75 \mathrm{p}$.

DAWSON, J.W. 1882. On the results of recent explorations of erect trees containing animal remains in the coal formation of Nova Scotia. Royal Society of London, Philosophical Transactions 173, pp. 621-659.

D'ORSAY, A.M. 1986. Stratigraphy and sedimentology of Carboniferous rocks in the northwestern Minas Basin and channel region of Nova Scotia. Unpublished M.Sc. thesis, University of New Brunswick, Fredericton, New Brunswick, $301 \mathrm{p}$.

GIBLING, M.R. 1987. A classic Carboniferous section: Joggins, Nova Scotia. Geological Society of America, Centennial Field Guide, Northeastern Section, 5, 88, pp. 409-414.

HAUBOLD, H. 1971. Ichnia amphibiorum et reptiliorum fossilium. In Handbuch der Palaeoherpetologie/Encyclopedia of paleoherpetology. Edited by O. Kuhn. Gustav Fischer Verlag, Stuttgart, FRG, Part 18, 124 p.

Haubold, H. 1974. Die Fossilen Saurierfahrten. A. Ziemsen Verlag, Wittenberg-Lutherstadt, GDR, 126 p.

HAUBOLD, H. 1984. Saurierfahrten. Die neue Brehm-Bucherei 479. A. Ziemsen Verlag, Wittenberg-Lutherstadt, GDR, 231 p.

MATTHEW, G.F. 1903. New genera of batrachian footprints of the Carboniferous system in eastern Canada. The Canadian Record of Science, 9, pp. 99-111.

MatTHEW, G.F. 1904. Note on the Genus Hylopus of Dawson. Bulletin of the Natural History of New Brunswick, 5, pp. 247252.

MATTHEW, G.F. 1905. New species and a new genus of batrachian footprints of the Carboniferous system in eastern Canada. Proceedings of the Transactions of the Royal Society of Canada, Section 4, 10, pp. 77-122. 
MCCARTHY, B.A. 1999. The Sedimentology and Palaeontology of the Parrsboro Formation at Rams Head, Cumberland County, Nova Scotia. Unpublished B.Sc. Hons. Thesis, St. Francis Xavier University, Antigonish, Nova Scotia, $54 \mathrm{p}$.

Mossman, D.J., \& GRANTHAM, R.G. 1996. A recently discovered amphibian trackway (Dromillopus quadrifidus) at Joggins, Nova Scotia. Canadian Journal of Earth Sciences, 33, pp. 710-714.

Mossman, D.J., \& PlacE, C.H. 1989. Early Permian fossil vertebrate footprints and their stratigraphic setting in megacyclic sequence II red beds, Prim Point, Prince Edward Island. Canadian Journal of Earth Sciences, 26, pp. 591-605.

NAYLOR, R.D., \& KENNEDY, C.M. 1997. Stratigraphy and sedimentology of the late Carboniferous Parrsboro Formation. Report of Activities, Nova Scotia Department of Natural Resources, 1997, pp. 115-126.

PEABODY, F.E. 1959. Trackways of Living and Fossil Salamanders. University of California Press, 71 p.

RYAN, R.J., BOEHNER, R.C., \& CALDER, J.H. 1991. Lithostratigraphic revision of the Upper Carboniferous to Lower Permian strata in the Cumberland Basin, Nova Scotia, and the regional implications for the Maritimes Basin in Atlantic Canada. Bulletin of the Canadian Society of Petroleum Geologists, 39, pp. 289-314.

SARJEANT, W.A.S., \& MOSSMAN, D.J. 1978 Vertebrate footprints from the Carboniferous sediments of Nova Scotia: a historical review and description of newly discovered forms. Palaeogeography, Palaeoclimatology, Palaeoecology, 23, pp. 279-306.

SCHMIDT, H. 1963. Herpetichnus erneri sp., eine Reptilfahrte aus dem westfálischen Oberkarbon. Palăontologische Zeitschrift, 37, pp. 179-184. 